\title{
The Urban Geopolitics of Neighboring: Conflict, Encounter and Class in Jerusalem's Settlement/Neighborhood
}

\section{Abstract}

This article examines a unique, yet paradigmatic, case study of a colonial neighborhood in East Jerusalem that is undergoing a significant demographic transformation. ${ }^{1}$ The French Hill neighborhood, built in 1971, was one of the first settlements in East Jerusalem. Initially, it was populated primarily by upper-middle class secular-Jewish residents. This group has been steadily diminishing as two other distinct new groups moved into the neighborhood: Ultra-Orthodox Jews and Palestinians. This volatile social mix has caused intense inter-ethnic and intra-ethnic collisions. Based on qualitative and quantitative studies, we argue that the juxtaposition of colonial and neoliberal logics of space reveals a shared, yet fragile, middle-class identity. We suggest that this new geopolitical space of neighboring calls for a discussion of political conflict, housing and current colonial conditions that brings class back to our understanding of the production of contested space.

\footnotetext{
1 This article forms part of the research "Patterns of Interaction and Conflict among Palestinians and Israelis in the French Hill" funded by the Tami Steinmetz Center for Peace Research.
} 


\section{Introduction}

"We will arrange street parties on Shabbat and make the Haredim ${ }^{2}$ understand that they are not welcome in the neighborhood. A Haredi that will come to this place should know that we won't allow him to build Sukkot [religious temporary structure] in the yards. We will insist on a secular environment in the public sphere. As for the kindergartens and educational institutions - we will fight to keep the institutions Zionist [...] The educated Arabs that live like us and integrate in the neighborhood do not bother me, and as for the Arabs of Issawiya, ${ }^{3}$ there is a struggle aimed at preventing them from moving into the neighborhood and changing its nature."

Gideon Yegger, Chair of neighborhood council of the French Hill (Kuperman \& Landa, 2009)

The French Hill (FH) neighborhood (officially named Giv'at Shapira) was built in 1971 as one of the first Jewish settlements in East Jerusalem. ${ }^{4}$ For many years it was an upper-middle class, mostly secular-Jewish neighborhood (Gonen, 1994). However, demographic changes since the 1980s have altered the city's ethnic and religious composition, while ongoing Jewish emigration (Choshen et al., 2017, table v/1), has increased the Arab portion of the city's population from 26\% in 1967 to $37 \%$ in 2015

\footnotetext{
${ }^{2}$ Haredim (plural) or Haredi (singular) refers to various groups of Ultra-Orthodox Jews in Israel, which are characterized by strict religious codes of behavior and rejection of secular culture.

${ }^{3}$ A Palestinian neighborhood in East Jerusalem located within the city's municipal border.

${ }^{4}$ The term "East Jerusalem" refers to 70 SQKM surrounding Jerusalem, which were unilaterally annexed by Israel following the Israeli occupation of the West Bank in June 1967. According to international law, East Jerusalem is considered as an illegally occupied territory. In contrast, the term "West Jerusalem" refers to the main Jewish part of the city, which was part of Israel before 1967, and is located today within the "Green Line."
} 
(ibid, table III/5). Correspondingly, within the Jewish population, the Haredi groups has grown substantially and become the largest Jewish sub-community in the city (ibid, III/19). These changes have transformed the demographic characteristics of several Jewish neighborhoods in Jerusalem, including FH.

While the veteran residents have emigrated from the neighborhood, middle class Palestinians, especially those with Israeli citizenship, ${ }^{5}$ and Haredi Jews have been drawn to FH due to low housing prices, good infrastructure and services, as well as proximity to, respectively, Palestinian and Jewish Ultra-Orthodox (Haredi) parts of the city. FH became the only residential area in Jerusalem which is cohabited by these three distinct and, until recently, highly segregated communities of the city, namely secular Jews, Haredi Jews and Palestinians (Rosen \& Shlay, 2014).

Another phenomenon has simultaneously contributed to the changes in the neighborhood: Palestinians from the neighboring villages in East Jerusalem - Issawiya, a-Tur and Shuafat began to make frequent use of the playgrounds, amenities and commercial center in FH (Yacobi \& Pullan, 2014). This was observed in recent years as well in some other Jewish areas in East and West Jerusalem (Shtern, 2016; Nolte \& Yacobi, 2015; Rokem \& Vaughan, 2017). The growing presence of both Haredi and Palestinian residents and transients alike has provoked considerable opposition among the long-term residents of FH. Driven by the fear of demographic transition, local

\footnotetext{
${ }^{5}$ Palestinian citizens of Israel are graduates of the Israeli educational system; thus, they speak very good Hebrew and are accustomed to interacting and engaging with Israeli society. In that respect, they differ significantly in their political and social status from the Jerusalem Palestinians, who mostly are not citizens, but have only a "permanent residential" status in Israel. Most of Jerusalem Palestinians study the Palestinian high-school curriculum, speak poor Hebrew and have minimal contact with Israeli society.
} 
activists and the neighborhood council were drawn into a series of conflicts over spatial and political control, as noted in the opening quotation of this article. Ideological movements and political coalitions were established in reaction to Haredi or Palestinian presence on one hand, and to represent an anti-racist agenda on the other.

In this way, a Jewish neighborhood/settlement with a predominant secular majority, which was integral to the colonization project of East Jerusalem (Yacobi \& Pullan, 2014), became ethnically and religiously heterogeneous. This neighborhood intersects the two major conflicts of contemporary Israeli space: the Israeli-Palestinian conflict, and the internal struggle between secular and ultra-Orthodox Jews. As such, we would argue, the FH neighborhood is one of the most paradigmatic sites of contemporary urban dynamics in Israel.

In this article, we present the findings from a questionnaire survey of 195 Israeli and Palestinian respondents, residents of FH. In addition, we have conducted 10 in-depth interviews with active residents from the neighborhood and an analysis of local news reporting, with the aim of describing the main ethnic/religious groups that reside in the neighborhood. This paper conceptualizes the ways in which class affiliations are relevant to the analysis of nationally contested spaces. Based on the case of the FH settlement/neighborhood in Jerusalem, we will demonstrate how ethno-national and class identities are entangled in the framing of new coalitions and territorial positionings in a context of spatial contestation. We aim to study the social order and power relation that has been constructed in $\mathrm{FH}$, not only between the macro political categories of Israelis and Palestinians, but also among social sub-categories: Jerusalem Palestinians, Israeli Palestinians, secular Jews and Haredi Jews. By intersecting these 
political and social identities we suggest an analysis of the geopolitics of neighboring in a dual context; being part of the colonial project of Judaizing East Jerusalem on the one hand, and an ordinary habitat which embodies transitions of neighborhood succession and opposition, on the other.

We propose that the social category of class should be revisited and understood as a potential sphere of habitation that can challenge the ethno-national divide. Without overlooking the very colonial politics of Jerusalem, we claim that neoliberal restructuring of the Israeli economy has promoted the development of a new middleclass among the two deprived minorities of Israeli society: Palestinians and Haredi Jews. Both are driven by neoliberal ideals, namely a set of political economic practices proposing that human wellbeing can best be advanced by "the maximization of entrepreneurial freedoms within an institutional framework characterized by private property rights, individual liberty, unencumbered markets, and free trade" (Harvey, 2007, 22). These two emerging sub-groups are drawn to mixed urban localities in which they can actualize their hybrid identities.

Therefore, the main contribution of this article lies in the nexus between urban and political geography. This theoretical combination is built on the understanding that geopolitics is a useful analytical framework for studying the production of space, politics of fear and everyday life in cities (Yacobi, 2009; Rokem \& Boano, 2017), and that urban geopolitics is a necessary prism through which to study neo-liberalization, ethno-nationalism and international migration, when the majority of world population is urban (Rokem \& Boano, 2017, Luz \& Stadler, 2017). In the case of FH, the ongoing Israeli-Palestinian ethno-national conflict and the subsequent Israeli colonial control in 
East Jerusalem frame the top-down geopolitical outline. On the other hand, the neighborhood itself, as an integral organ of the city of Jerusalem, extracts bottom-up resilient urban logics that adopt or challenge the macro geopolitics (Bollens, 2018).

Importantly, this article employs a new approach towards the study of East Jerusalem. While most urban scholars focus on modes of domination, control and colonial practices (i.e. Shlomo, 2017, Chiodelli, 2016, Dumper, 2014), we also account for the role of "ordinary" urban phenomena (Robinson, 2013; Rosen \& Charney, 2016) in the construction of residential space in East Jerusalem. Notwithstanding the colonial apparatus, we emphasize the function of neighborhood transitions, urban neo-liberalism and especially class affiliation as important factors in understanding contemporary urban geopolitics. Therefore, we refer not only to the post-colonial framework, but also to the production of urban spaces in the age of the globalization of neo-liberalism. We live in an era in which Jerusalem appears to have become a "paradigm for urban studies [..] signifier of future urbanisms" (Boano, 2016, 457), where Western cities are being "Jerusalemized," transforming into sites of not only racial and ethnic collision, but also of re-emerging ethnonational identities (Kinnvall, 2016). Thus, learning from Jerusalem's geopolitics can illuminate hidden or future complexities in global contemporary urban spaces.

This article opens with our theoretical framework, contextualizing the urban geopolitics of FH and its transformation. Here, we will also present how the perception of the role of class has evolved in accumulated literature on nationalism, geopolitics and urban space. In the second section, we will provide a chronology of $\mathrm{FH}$ demographic transitions from 1967 until the present. In the following section, we will present the results of our survey and the ways in which Israeli and Palestinian inhabitant groups in 
FH contest and negotiate its territorial identity. Finally, in the discussion section we will conceptualize the urban-colonial dialectics of FH and the suggested relevance of class affiliations to the study of ethno-nationally contested spaces in a neoliberal era.

\section{Urban Geopolitics, Ethno-nationalism and Class}

One of the central discussions in urban studies is the interrelationships between the production of urban space and the power relations that shape it. The sub-field of urban geopolitics has stemmed from the study of urban political geography, engaging with the militarization of urban space, security and surveillance in an age of global terrorism (Crang \& Graham, 2007; Graham, 2008; Waquant, 2008; Rokem \& Boano, 2018). This sub-field has attempted to scale down geopolitical focus from inter-state relations and territorial control to urban arenas and local sites (Fregonese, 2012; Yacobi, 2009). In the last decade, many studies have focused on urban conflicts within ethno-nationally contested cities, especially in relation to the role of urban planning (f.e. Braier \& Yacobi, 2017; Gaffikin \& Morrisey, 2011; Bollens, 2018; Rokem, 2016). The influential works of Dumper (2005), Bollens (2000) and Pullan (2011), among others, provide illustrations of the powerful - and regularly explosive - links between the drive for ethnic control over national space and the conflictual reality of ethnically mixed cities and regions.

Despite extensive discussions of cities and nationalism in general, there have been very limited attempts to engage seriously with the tensions and relations associated with the simultaneous effect of two major structural forces shaping contemporary cities, namely class and ethno-nationalism. It is beyond the scope of this article to discuss this matter in depth; however, we refer to the Marxist critique that focused on modernization, industrialization and class classifications as major actors, which influence urban 
dynamics and urbanization processes that produce and reproduce social stratification and wealth. This position characterized Marxist critique until the 1970s, when the identification of the forces operating in the urban space had changed. This shift points to other factors - in addition to class - that shape the social, political and cultural space of the capitalist city (Castells, 1978). The significant stage in the development of this concept, also referred to as neo-Marxism, suggests that although class should be seen as an important element in understanding urban processes and conflicts, it must be understood as a component within a framework of other identities including gender, ethnicity and race (Castells, 1983, 291). Even the recent seminal work on ethno-national contested cities (Bollens, 2018; Dumper, 2014; Pullan, 2011) has tended to favor issues of national control over the urban dynamics and everyday life in the city, concealed beneath the more visible national surface - a lacuna that this article aims to fill.

In this paper, we emphasize the relevance of urban geopolitical micro-analyses of the neighborhood's scale, by examining layers of neighborhood transitions, urban culturalreligious contestation (i.e. the Haredi/secular conflict) and the role of middle-class identity in residential spaces, we are advancing a more nuanced understanding of urban processes. Indeed, instead of focusing solely on top-down forces of division and exploitation, we suggest studying the city as "a contested space, as an arena of power relations where also 'bottom-up' protest, global forces and a wide spectrum of political institutions (NGOs, [non-governmental organizations], religious organizations, professionals) produce and reproduce urban space." (Yacobi 2015: 583) 


\section{Israeli Urban Space and Neighborhood Transitions}

Since the establishment of the State of Israel, the demographics of Israeli urban spaces have evolved in terms of the tension between ethno-national and economic transitions. Between 1948 and the 1970s most of the Israeli housing market was centralized and regulated by the government. Key planning rationales were (and still are) determined by ethno-national policies of division and territorial control (Yiftachel, 1994), aimed at reinforcing Jewish spatial domination. This top-down imposed and fostered segregation was created along multiple fault lines: ethno-national (Jews/Arabs), Jewish ethnic origin (European/Arabic/Russian/Ethiopian), Jewish religious-cultural identity (secular/Modern-Orthodox/Ultra-Orthodox), ideological (Kibbutz vs. Moshav) and socio-economic (social housing/private compounds) (Tzfadia and Yacobi, 2011). Thus, until the 1970s, residential mobility and neighborhood demographic transitions were limited and marginal (Gonen, 1994).

Significant trends of ethnic and national diversification in the neighborhoods became dominant once the national economy and urban culture entered the globalization era, and the housing market was privatized (Yacobi and Tzfadia, 2017). Nationwide liquidation of agricultural lands, which began in 1991 and were followed by dramatic suburbanization processes, has led to the transformation of the Israeli urban humanscape. While upper-middle-class Jews moved to the new suburbs, other populations entered urban centers in Israel, among them Russian and Ethiopian Jewish immigrants, global labor migrants and African refugees. However, the two most significant groups, which are situated at the center of our discussion, that have profoundly challenged the predominant homogenous nature of middle-class Israeli neighborhoods are IsraeliPalestinians and Ultra-Orthodox Jews. 


\section{Palestinian Migration to Jewish Localities}

Since 1948, Palestinian towns and villages in Israel have been economically deprived and spatially limited (Yiftachel, 1994; Falah, 1996). New Jewish-Israeli towns, such as Carmiel and Upper Nazareth, were established on expropriated Palestinian land in order to strengthen Jewish domination in frontier territories (Hamdan, 2006). Though outmigration from Palestinian to Jewish localities began as early as the 1960s, it has rapidly grown since the 1990s (ibid).

While Israeli-Palestinian intra-immigration to Jewish and mixed towns is diverse (Yacobi, 2009), the more significant groups are students and nuclear families (MasryHerzallah \& Razin, 2014). These movements take place due to various push and pull factors: on one hand, shortage of land, insufficient housing and lack of job opportunities in Arab villages and towns (Al-Haj, 2012); on the other hand, relocation for purposes of higher education and search of a higher quality of life (Arar \& Haj-Yehia, 2016), as well as liberation from a confining traditional and gendered order (Herzog, 2007).

When Israeli-Palestinians move further away from their hometowns, they may experience disconnection from their communities that may be translated to a loss of identity and belonging (Pullan \& Yacobi, 2017). Furthermore, there is evidence that in spite of the growing geographical proximity in the new locations, Israeli-Palestinians retain high social segregation from their Jewish neighbors (Goldhaber, 2007; BlatmanThomas, 2017). The growing presence of Palestinians in Israeli Jewish and mixed cities has prompted negative reactions from local Jewish residents who fear the loss of domination and the decline in housing prices (Falah, 1996; Monterescu, 2016). Thus, 
Palestinians in Jewish-Israeli towns face discrimination in housing (Pullan \& Yacobi, 2017), as well as local political opposition (Shafir, 2018).

Israeli-Palestinians began to immigrate in considerable numbers to Jerusalem following the occupation of East Jerusalem in 1967. Primarily in order to study at the Hebrew University, some of them settled in the city and composed a solid layer of a middle class, professional and social group. Since they were fluent in both languages they were absorbed in the local labor market, as a "middle-man minority," mediating between the Israeli establishment and the local Palestinian population (Masry-Herzallah \& Razin, 2014). Being neither part of Jerusalem's Jewish society nor of East Jerusalem's Palestinian society, Israeli-Palestinians have experienced "double marginality" in Jerusalem (Weingrod \& Manna, 1998). As housing densities grew in East Jerusalem and physical conditions deteriorated following the Second Intifada, more IsraeliPalestinians moved to Jewish neighborhoods in the city (Masry-Herzallah \& Razin, 2014). Among these, one of the most popular destinations is the FH neighborhood.

\section{The Modern Haredi Middle Class}

Since the beginning of the twentieth century, the Haredi population in Palestine has preferred to maintain territorial segregation of their dwelling spaces by maintaining clear boundaries from the outer, secular world. The spatial division serves as a means for facilitating the socialization of the younger generations into the Haredi society and for the prevention of their exposure and assimilation into the surrounding secular society and culture (Shilhav, 1993; Efron 2003). Thus, for many years most of the Haredi population lived either in Haredi towns or in Haredi enclaves within cities. Yet, due to their ongoing demographic growth (Rebhun \& Malach, 2012), Haredi Jews are 
constantly expanding their residential territories by moving to new locations. This expansion, which takes form alongside a concurrent process of cultural and social introversion, fosters constant territorial struggles with local non-Haredi populations (Efron, 2003).

In Jerusalem, Haredi Jews were always a dominant group among the general Jewish population. However, until the 1960s, they were concentrated northwest of the Old City (Shilhav, 1984). The demographic growth led to spatial residential expansion to adjacent neighborhoods, to Haredi-designated neighborhoods, or to non-Haredi neighborhoods in which housing prices were affordable. In order to maintain the properties of a controlled space, codes of Haredi behavior were imposed on new territories (Gazit, 2010; Rosen \& Shlay, 2014). Thus, territorial struggles between the Haredi community of Jerusalem and secular or Modern-Orthodox communities have become one of the dominant features of West Jerusalem's local politics (Hasson, 2002).

In the last decade, scholars have identified sub-current trends of class mobility and Israelization within Haredi society (Cahaner \& Mansfeld, 2012; Zicherman \& Cahaner, 2012). The introduction of smartphones and exposure to the internet have undermined the imposed information closure on community members, alongside a growing tendency towards consumption culture. Economic demand for better employment has led to the formation of a new social layer of integrated modern Ultra-Orthodox. These modern Haredi groups prefer to live in mixed localities, on the edges of classic Haredi neighborhoods, where they alternate between Haredi facilities and non-Haredi services (Ibid). However, despite their modern character, their presence in non-Haredi residential urban spaces is still perceived by many secular residents as invasive and domineering (Shteinmatz, 2016). 


\section{A Colonial-Neighborhood in Transition}

Following the War of 1967, the Israeli government unilaterally annexed East Jerusalem, expanded the municipal boundaries and applied Israeli law to all of the city. These measures were taken despite international objection and lack of recognition. Beyond Israeli rhetoric representing Jerusalem as a unified city, the planning policies have contributed to the paradigm of a colonial city (Pullan \& Yacobi, 2017). Both the state and the city pursue these policies, which have persistently promoted the expansion of Jewish political, territorial, demographic and economic control to all parts of the city.

As already discussed (Yiftachel \& Yacobi, 2002; Dumper, 2014; Shlomo, 2017), Israel has used its military might and economic power to relocate borders and boundaries, grant and deny rights and resources, shift populations and reshape the occupied territories to ensure Jewish control. In the case of East Jerusalem, two complementary strategies have been implemented by Israel: the massive construction of an outer ring of Jewish neighborhoods (including FH), which now houses over half of the Jewish population of Jerusalem, and the containment of Palestinian development, implemented through housing demolition, the limited issuing of building permits, the establishment of national parks along the edges of areas of Palestinian habitation and the prevention of immigration to the city. Furthermore, Israel has also maintained control of most infrastructures, even those that serve the Palestinian population such as major access roads (Dumper, 2014).

It is within this colonial logic that an analysis of FH's transformation should be understood. In July 1967, the Israeli Prime Minister's office began planning the first settlement strip in East Jerusalem, including four Jewish neighborhoods that created 
physical continuity between Northwest Jerusalem and the former enclave of Mount Scopus - Ramat Eshkol, Maalot Dafna, Giv'at Hamivtar and FH.

As noted by Yacobi and Pullan (2014), the initial demographic goal for FH was to house 2,400 Jewish families. This number increased later due to a decision to allocate 37 dunams (approx. 9 acres) for the expansion of the Hebrew University campus. Public buildings were located on the eastern slope of $\mathrm{FH}$ and the housing zones were designed around the hilltop. The design scheme proposed separation of cars from pedestrians, and most housing units were planned in four-story buildings. At the time, many of the planning decisions reflected a cutting-edge approach to modern housing.

In December 1969, the Rogers' Plan (named after US Secretary of State William Rogers) was published, calling for a shared administration of Jerusalem by representatives of the three main religions. This recommendation was rejected by the Israeli authorities and as a result the plans for low-rise housing in $\mathrm{FH}$ were pushed aside and three to four floors were added to each building, in order to intensify the Jewish presence in East Jerusalem (ibid). The new neighborhood included a Palestinian enclave of former Palestinian refugees who fled their village, Lifta, in West Jerusalem during the 1948 War (Morris, 1989: 76), and resettled on their own properties north of Jordanian Jerusalem. The "Liftawee compound" has grown and developed during the years and became a relatively prestigious Palestinian sub-neighborhood in East Jerusalem, attached to FH (Figure 1).

The neighborhood was initially designated for upper-middle class Jews and many of the establishing communities during the 1970s were either immigrant Jews from North America and Western Europe or families of Hebrew University faculty (Al Hamishmar, 1968, Gonen, 1994, 58-60). In socio-political terms, they were related to the Israeli 
establishing Ashkenazi, liberal and secular hegemony (Kimmerling, 2001). However, during the events of the First and Second Intifadas (1987-1991; 2000-2004), FH was caught in the "line of fire" between Israeli security forces and Palestinian protestors from its surrounding villages. The university and the road junction at the entrance to the neighborhood were both targets of terroristic attacks, and the overall sense of security in the neighborhood diminished (Savitch, 2005). Property values declined, the affluent establishing communities began to emigrate, and the neighborhood entered a new demographic period of ethnic and national hybridization. Thus, in the last two decades, the diminishing establishing upper-middle class secular-Jewish population of FH, was joined by two distinct new groups: Haredi Jews and Israeli-Palestinians.

Official data indicates that in 2015, the number of inhabitants in $\mathrm{FH}$ (including the Liftawee compound) was 7,241 , of which $78 \%$ were Jewish inhabitants, $18 \%$ were Arabs (Muslim, Christians and Druze) and 4\% were non-Arab Christians and others. (ICBS, 2017). There is no official data regarding the exact size of the Jewish Haredi community in the neighborhood. However, there are sources that can indicate their current extent. In the national elections of $2015,6.3 \%$ of the neighborhood residents eligible to vote had voted for Haredi parties (Choshen et al., 2015, table XVI/22). Also, according to the Jerusalem municipality, in 2016, 28\% of the children living in FH went to Haredi kindergartens (Jerusalem Municipality, 2017). Overall, we estimate that in 2017, FH's population was grossly composed of: 55\% - secular and traditional Jews; 20\% - Palestinians (Israeli and Jerusalemites); 15\% - Ultra-Orthodox Jews; 5\% National-Religious Jews and 5\% others.

\section{French Hill Revisited}


With this background in mind, we now present the results of our survey, conducted between June 2016 - October 2017. The research included a questionnaire survey in Hebrew and Arabic. Respondents to the questionnaires were residents of FH, composed of 195 adults, 110 Jews and 85 Palestinians. Among the Jewish respondents, 74 were secular Jews ${ }^{6}$ and 36 were Haredi Jews. Among the Palestinian respondents, 52 were Israeli-Palestinians and 33 were Jerusalem Palestinians. Of the questionnaires, 48\% were distributed in a digital version through email lists and Facebook groups, and 52\% were manually circulated and delivered by an Israeli/Palestinian team in the local commercial center.

The choice to divide the respondents into these four social/ethnic groups stems from our extensive observation that these categories represent the main dominant sociopolitical divisions in the neighborhood. However, it is important to note that secular Jews, Haredi Jews and Israeli-Palestinians are all Israeli citizens, relatively accustomed to the Israeli social space and live in mixed residential buildings. Jerusalem Palestinians, on the other hand, are not Israeli citizens, they live in a politically and socially isolated environment and geographically reside in a segregated compound at the southern end of the neighborhood ('The Liftawee Compound').

The survey used both open and closed questions, aimed at assessing the attitude and sense of belonging of the respondents to the neighborhood, and the quality and quantity of their social relationships with other group members. Thus, the questionnaire related to issues regarding the residents' motivations for choosing to live in the neighborhood, their level of satisfaction from various factors as well as services provided in the

\footnotetext{
${ }^{6}$ Including traditional (“Masorti”) Jews.
} 
neighborhood and their social relations with both their in-group and with out-groups' residents.

Ten in-depth interviews were conducted with Israeli and Palestinian residents of FH, which represent the various social sub-groups. In addition, we used textual analysis and archival investigation to examine written sources about FH. This entailed coding for emerging and recurring themes and categories (Charmaz \& Mcmullan, 2011). Acknowledging the limitations of our non-representative survey, we have employed a mixed methodology (Johnson et al., 2007). The integration of fieldwork and the quantitative survey serves to strengthen both methodologies, avoid holistic fallacies and clarify as well as validate the results of each analysis (Sieber, 1973).

\section{The Search for "Quality of Life"}

As shown in earlier studies (Masry-Harzzallah \& Razin, 2014; Yacobi \& Pullan, 2014), many Israeli-Palestinians choose to live in FH due to its relatively high standard of living, its seamline location between East and West Jerusalem and its proximity to the Hebrew University and the Hadassah Hospital. Our survey shows (Table 1) that the dominant factor in the Israeli-Palestinian respondents' choice to live in FH was "quality of life," followed by location-related factors as secondary motivations to move into the neighborhood. Moreover, the profile of the Israeli-Palestinian respondents reflects an upper-middle class socio-economic status: $84 \%$ of them have tertiary education qualifications and $46 \%$ hold academic and professional occupations.

A dominant theme among our Israeli-Palestinian respondents was their deliberate choice to live in a Jewish neighborhood. Many of them tend to consume community services in the neighborhood community center, take part in recreational events and 
some even send their children to the local Jewish kindergartens and elementary school (L.E., personal interview, September 20, 2017). H., an Israeli-Palestinian employed in an Israeli government ministry, is an example of a highly integrated Israeli-Palestinian inhabitant of the neighborhood. She told us that FH is the only place in Jerusalem in which she and her family can live:

There's a large concentration [in FH] of Arabs from the north, and I never thought about living elsewhere in East Jerusalem. It's a different population, [elsewhere in East Jerusalem], different customs, they teach [at schools] the Jordanian curriculum and the living conditions there... [are] not even worth considering.

(H., personal interview, October 3, 2017).

Many of our Israeli-Palestinian respondents stated that they have good relations with their Jewish neighbors, and that they do not experience overt racism in their daily lives in the neighborhood: "A relationship of good neighboring"; "Few (inter-group) connections, but good relations with our Jewish neighbors based on mutual respect." However, it seems that tolerance ends when it faces formal real-estate acquisitions. FH as a Jewish residential space holds considerable obstacles for them. As Yacobi and Pullan (2014) have shown, Palestinians who try to rent or buy an apartment in the neighborhood face discrimination, avoidance and are even expected to pay an additional fee for competing with Jewish buyers. Furthermore, Israeli-Palestinians have no designated educational or community services in FH. If they wish to send their children to Arab kindergartens or schools they must send them to one of the Palestinian neighborhoods in East Jerusalem (N. K., personal interview, August 19, 2017). Thus, for Israeli-Palestinians scaling up in Jewish-Israeli localities such as $\mathrm{FH}$ - means not 
merely socio-economic mobility, but a process which constantly reveals their structural inferiority as Arab-Palestinians within the Israeli social space.

Our findings show a striking similarity in the socio-economic profile and residential preferences of the Israeli-Palestinians and Haredi Jews. Interviews with Haredi residents show that most Haredi inhabitants of $\mathrm{FH}$ are part of the rising Haredi middle class (Zicherman \& Cahaner, 2012). They are attracted to the neighborhood not only because of the lower housing prices and good services, but also since principally they prefer to live in a mixed locality (Table 1). Until recently, Haredi Jews did not receive designated educational services in FH. Only after a prolonged political campaign against the neighborhood city council and a mediation process did they managed to achieve in 2017 a legal status for two Haredi kindergartens (FHNC, January 31, 2017). The profile of our Haredi respondents indicates that a high percentage (61\%) are engaged in "secular" occupations, such as university students, high-tech engineers and lawyers. As quoted in the previous chapter, modern Haredi Jews are drawn to neighborhoods with diverse populations, which allow them to alternate between both worlds. E., a Haredi resident, suggests that these preferences are related to notions of individualism and a search for privacy:

We are the type of people who don't want to live in a Haredi Chulent pot [traditional Jewish dish], but prefer to live in a quieter area, an area which is not completely Haredi. We're not looking to live with hilonim [secular Jews], but seek a place where each family can live independently, within itself, rather than a place where everyone interferes in everybody else's lives.

(E. E., personal interview, September 25, 2017). 
Albeit major differences in their ethno-nationality and political position in Israel, as shown in Table 1, the search for a residential space with good "quality of life" was a major drive for both Haredi Jews and Israeli-Palestinians to settle in the neighborhood. Other influential factors are related to the neighborhood's location, its housing prices and diversity. It seems that the sociological context of the immigration of both groups to $\mathrm{FH}$, relates to modern ambitions for freedom from traditional community boundaries. However, as we will show in the following section, the Haredi presence in FH fosters greater resentment and active political rejection by the Jewish secular group.

\section{Fearing Diversity}

Secular Jews are the largest demographic group in FH. Among them are the most veteran families in the Jewish neighborhood. To this day, this group is characterized by a high socio-economic status and Zionist-liberal political tendencies. ${ }^{7}$ In the last decade, a renewed wave of immigration of young secular Jewish families has somewhat revived this community (N. K., personal interview. September 19, 2017). Nonetheless, aging and emigration have diminished their ratio in the neighborhood throughout the years.

The growing presence of Palestinians and Haredi Jews in the neighborhood has instigated diverse reactions from the secular Jewish majority. Despite their similar demographic size, it seems that the Haredi presence is perceived as a much more threatening "invasion" than that of the Israeli-Palestinian. In the survey, most secular Jews reported minimal social connections and expressed negative reactions to intergroup encounters with both Haredi Jews and Muslim Arabs, however, the extent of

\footnotetext{
${ }^{7}$ This is evident in the fact that in the last elections, the most popular national party was the Israeli Social Democratic Party - the Zionist Camp (JIPR, 2015: table XVI/22).
} 
social segregation and negative reactions was slightly greater towards the former group than towards the latter (Tables 2 and 3.) $)^{8}$

Moreover, the dominant theme among secular Jewish respondents revealed a clear distinction between their reactions to both communities:

We have good neighboring relations, but not with the Haredim. They don't give (you a) good feeling. They make you feel uneasy, not wanted.

We have excellent relations with the Arab population that lives in the neighborhood and is educated in our schools/kindergartens. This is one of the most valuable things that are happening here. Unfortunately, this co-existence happens less with national-religious people, and not at all with the Haredim.

As one of the leading Jewish liberal activists in the neighborhood explained:

Everyone has their limits regarding pluralism. The secular community is terrified of the Haredim, but willing to accept the Arabs. They (the Israeli Palestinian residents) are very close to us culturally.

(C. B., personal interview, August 27, 2017).

An analysis of local news reports and protocols of the neighborhood council (French Hill's Neighborhoods Council) also demonstrate that the main political efforts of the secular Jewish members were devoted to diminishing what they perceive as Haredization - a complete succession of the neighborhood by Haredi residents.

\footnotetext{
${ }^{8}$ When we conducted the survey, we asked the respondents to characterize their relations with five groups according to their religious identity (which seemed most relevant at that stage): Secular Jews, Religious Jews, Haredi Jews, Muslim Arabs and Christian Arabs. However, after analyzing the results, we chose to divide the respondents into the current main four sample groups: secular Jews, Haredi Jews, Israeli-Palestinians and Jerusalem Palestinians. This explains the unique group juxtapositions of Tables 2 and 3.
} 
The secular Jewish majority of the neighborhood council has politicized its activities since the late 2000s, mobilizing the Community Center's assets as part of the struggle against Haredi succession. Activities such as a campaign using street advertising that portrayed women of the neighborhood (Zorea, 2017), organizing Shabbat cultural events (Malcov, 2012) and rebranding the neighborhood as a university quarter (FHNC, April 29, 2013), were all directed to sketch FH as a secular space, therefore unsuited for Haredi residents. This was the reaction of Elie Rosenfeld, the chair of the neighborhood council since 2013, regarding the municipality's designated budget for Haredi cultural events:

My terms are clear - these activities will not take place in FH, but in Ramat Eshkol only. If I would be pressed to start these activities in FH, and I would see that it is advancing towards here, I would consider this as a red line and I would cancel everything.

(FHNC, March 3, 2014).

As part of a larger diminishing ex-hegemonic minority of secular Jews in Jerusalem (Hasson, 2002) the secular Jews of FH fear a demographic transformation similar to other formerly secular neighborhoods. The fear of 'Haredization' in many ways overshadows other inter-group collisions.

\section{Choose Your (Urban) Battles}

As shown in our study, secular Jews and Israeli-Palestinians have both reported positive neighboring relations. However, in the survey's closed questions, while IsraeliPalestinians reported a relatively significant average of social connections with secular Jews (Table 2), and a relatively positive influence of their daily encounters (Table 3), the secular Jewish respondents have evaluated the same inter-relations negatively in 
both questions. This apparent contradiction between the qualitative and quantitative results can be explained with an overall non-distinction of the secular Jewish respondents between the different Palestinian groups in the neighborhood. As portrayed by one of the secular Jewish respondents in our survey regarding the daily presence of the transient local Jerusalemite Palestinians in FH's public spaces:

As someone who grew up in the neighborhood, I witnessed the downfall of the neighborhood, from a prestigious and clean place, with well-kept gardens, a sense of security and views to the Judean Desert, into a frontier neighborhood which has a public space that is controlled by gangs of Arabs from Issawiya, Shuafat and Anata. The over-tolerance and liberalism of the population has led to the theft of the public space. This is a suicidal liberalism.

Indeed, these relations between Jewish residents of FH and the adjacent Jerusalem Palestinian neighborhood - Issawiya, take place within the context of ongoing volatile interactions and daily encounters in public spaces. The two communities are divided not only along opposing ethno-national identities (Israeli-Jews vs. Palestinian-Arabs), but also along clear socio-economic cleavage and contradicting cultural affiliations. The former being composed of mostly middle-class westernized-liberal Jews and the latter of impoverished and conservative Muslims (Issar, 2016, 14-17). In times of political upheaval, the open space between the Jewish neighborhood and the East Jerusalem Palestinian village becomes a potentially explosive frontier, a clashing zone between Israeli security forces and Palestinian demonstrators (Ibid, 51). As such, many Jewish residents of $\mathrm{FH}$ see the village as a source of political violence, criminal activities and sexual harassments, which is "invading" the neighborhood (Malcov, 2010). 
Nevertheless the neighborhood's commercial center provides services to many Issawiya Palestinians who regularly use the post office, bank, supermarket, cafés and restaurants. In the last decade, Palestinian presence in the commercial center has become so dominant, that currently some of the businesses in the center are operated by Palestinians and address both groups (N. K., personal interview, August 19, 2017) (Figure 2).

The Jewish population of FH is divided regarding the Palestinian presence. In July 2014, racist Jewish activists burnt down a kindergarten classroom in the Bilingual School in south Jerusalem. Following the incident, some 50 Jewish and Arab families from FH formed a local bi-national community called Ma'an-Yahad (meaning "together" in Arabic and Hebrew). The group celebrates inter-faith holidays together and lobbies to include Arabic language classes in the Jewish elementary schools in the neighborhood (A. H., personal interview, October 6, 2017).

In contrast to the inter-ethnic solidarity reflected in the actions of the bi-national group, for some other Jewish groups Palestinian presence is seen as a threat to the "Jewish identity" of the neighborhood. They emphasize the ways in which Palestinians, both Israeli and Jerusalemite alike, undermine its Jewish character and incite Jewish emigration. The dominant group among these extremists is the national-religious community, called Nofet Tzofim (idiom for gentle and pleasant). Derived from a religious ethnocratic ideology, this group has constant disputes with the community center's secular management and with the bi-national community (N. K., personal interview, August 19, 2017). Nofet Tzofim conducts frequent cultural and religious events characterized by Jewish Orthodox contents. They have identified the commercial center as a space that requires enhanced Jewish presence. For that purpose, they initiated a series of Jewish-religious concerts in one of the local cafés throughout 
the winter of 2017 (S. S., personal interview, September 26, 2017). In their Facebook page description, they wrote:

We chose the FH neighborhood because of the unique challenges that face Jerusalem, and FH in particular: emigration of young families, alienation from the city... and the absence of appropriate religious education in the neighborhood and emigration of Jews. In addition, FH is a borderline neighborhood, and is unpopular due to security problems in recent years. We are working to strengthen the sense of security in public spaces, with an emphasis on strengthening the commercial center (Nofet Tzofim, 2017).

Ma'an-Yahad and Nofet Tzofim reflect opposed reactions of residents to the changing ethno-national human-scape of FH. While the first group aspires to normalize its binational character, the latter fights for Jewish spatial dominance. However, it seems that political tensions mostly take place among local activists and in neighborhood council discussions. As noted by our interviewees and respondents, daily neighboring relations between the different group members are usually calm and ordinary - and in general, the inhabitants of FH are satisfied and content with their place of residence. This exemplifies the ongoing tensions in FH between ordinary middle-class daily life and the sensitivities over ethno-national territorial identities in Jerusalem.

In summary, our investigation has revealed the ways in which various groups are contesting and negotiating the territorial identity of FH. It has become a space of mixed residency and daily encounters of diverse Israeli groups that live mostly in segregated enclaves. Concomitantly, its initial ethno-national logic as a Jewish urban settlement in East Jerusalem still dominates its political hierarchies and power structure. 


\section{Towards Israeli Urban Geopolitics}

Our geopolitical analysis of the FH neighborhood/settlement reveals its inner ethnonational and cultural stratification of power. Since its establishment, the hegemonic group in the neighborhood has been the secular Jewish community. As a demographic majority, they dominate the neighborhood's council, and throughout the last decade they have leveraged their political power in an effort to maintain their control and cultural hegemony. Yet since the 2000s, the group's stronghold has been contested by the new rising actors - the religious Jewish communities (National-Religious and UltraOrthodox). These groups diversify the territorial identity of the neighborhood and challenge the secular-liberal hegemony.

The various Palestinian groups hold an inferior position of power and their political position correlates to their level of integration within the Israeli systems. The community of Israeli-Palestinians is the more privileged group (in relative terms). They live amidst the Jewish population, use its social and educational services and claim cultural recognition through the introduction of Arabic language classes to the elementary school and the celebration of Muslim holidays in public community events (though this only happens through a mutual Jewish-Arab civic cooperation). The Israeli-Palestinian residents are perceived as sharing a similar class affiliation by the secular Jewish majority, and are not seen as undermining the cultural status-quo. In contrast, the Jerusalemite Palestinians are perceived in more negative terms. They use the commercial and physical infrastructure of the neighborhood, and their presence, albeit mostly transient, is perceived as invasive and threatening by some of the Jewish population. As non-citizens, these Palestinians are of a poorer background, and are seen 
as disruptive to the middle-class identity as well as to the Jewish-Israeli territorial character of the neighborhood.

Geopolitically, FH embodies two parallel political typologies: by its initial logic, it's a settlement, an integral part of the colonial project of Judaizing East Jerusalem. By means of zoning, social services and budget allocation, it is designated for Jewish residents, while non-Jews are not eligible for particular public community services or institutions. However, as part of the urban realm of Jerusalem, it also functions as an "ordinary" neighborhood, where daily access and residency (by rent or by ownership) are unregulated, thus subject to the Israeli housing free-market dynamics.

As a neighborhood, the gates of FH are open to Palestinian daily users and residents. This locality is also influenced by other urban dynamics that take place in West Jerusalem, such as Haredi territorial expansion and secular emigration. Within the settlement-neighborhood dialectics, ideological groups that are active in FH attempt to influence and shape the neighborhood's territorial and cultural identity. The nationalreligious group Nofet Tzofim strives to drive the place back to its initial colonial logic, through religious Judaization. In contrast, the bi-national community Ma'an-Yahad campaigns for the neighborhood's urban nature by normalizing Israeli-Palestinian coresidency.

FH is located also in a "socio-economic junction," as a middle class residential space offering a relatively high standard of living (in Israeli terms). It has become an affordable neighborhood for the emerging Israeli-Palestinian and Haredi middleclasses, which prefer to live on the physical margins of their home territory. Our survey displays that both populations are attracted to the neighborhood's "quality of life" and physical infrastructure, which are more developed and better maintained in comparison 
to Palestinian or Haredi neighborhoods in Jerusalem. The class identity shared by most residents provides enough common ground for peaceful neighboring, while maintaining social group boundaries. The secular hegemonic group therefore expresses an inclusive attitude towards the Israeli-Palestinians because of their cultural suitability, perceived as sharing similar class values.

However, it seems that middle-class Haredi residents are not perceived as part of the same socio-cultural class and the Jewish-secular hegemonic majority views them as a political and cultural threat. We assume that the difference in attitude derives from the different political status of the two new communities. While the Israeli-Palestinians have no organized leadership, and make no demands for political control, the Haredi group in the neighborhood has political claims backed by its political power in the municipal arena. Thus, the Israeli social order of a Jewish dominated hierarchy frames ethnic and class relations in the neighborhood.

We suggest that the underlying logic of this process is defined by the social transitions of the neoliberal era, in which "individual freedom is redefined as the capacity of selfrealization [..] with human behavior reconceptualised along economic lines" (Leitner et al., 2007, 4). However, our study shows that while neoliberalism reconfigures spatial segregation and the ethnic division of social classes, it does not undermine the overall ethno-national hierarchies of Israeli society.

\section{Conclusions}

In this article we proposed an urban geopolitical analysis of $\mathrm{FH}$ - a settlement/neighborhood in East Jerusalem. Based on a survey and extensive fieldwork, we demonstrated the ways in which, in the wake of considerable demographic transitions, FH has become a junction of two dominant axes of Israeli socio-political 
contestations: the Israeli-Palestinian ethno-national conflict and the secular/Haredi hegemonic struggle. In this unique intersection, the category of class affiliation has evolved as a crucial factor in the understanding of the negotiation of space between predominant rival communities that found themselves sharing the same residential space. In light of the ongoing immigration of both middle-class Palestinians and Haredi Jews to predominant Israeli Jewish (non-Haredi) cities, we propose that $\mathrm{FH}$ is a paradigm for future Israeli urban spaces. It illustrates the need to promote more nuanced analyses of micro-urban geopolitical study cases that can demonstrate the important juncture of neoliberalism, colonialism and ethno-nationalism in contemporary urban spaces in Israel and worldwide.

The study of ethnic conflicts tends to focus on state borders and national territories, ignoring the relevance of such analyses to the urban realm. In this context, some researchers (Newman, 2006) propose that the impact of borders and territoriality is not diminishing; rather, new scales of territorial affiliations and borders are recognizable, which may be flexible but are still selective on a different geographical scale. Indeed, we can conclude that it is necessary to focus on the geopolitics of neighboring in the study of cities. Furthermore, urban geopolitics differ from discussions of international relations and conflicts, or of the roles of military acts and wars in producing space. Rather, urban geopolitics refers to the emergence of discourses and forces connected with technologies of control, patterns of internal migrations by individuals and communities, and the flow of cultures and capital (Yacobi, 2009; Fregonese, 2012; Rokem \& Boano, 2017).

The urban geopolitics of FH shows the relevance of class, as a dominant neighboring inter-ethnic identity, for the highly politicized geographies of the colonial neighborhoods of Jerusalem. We argue that further study of ethno-nationalist cities 
should relate to socio-economic class affiliations of people, groups and spaces as crucial factors in the analysis of urban domination and colonialism. Throughout history, cities have functioned as socio-political arenas where different classes, ethnic groups, migrants and "strangers" interacted (Bauman, 2013). Indeed, situations in which "strangers become neighbors" (Sandercock, 2000) are highly political and involve protests, violence and sometimes acceptance - these experiences have become embedded within urban life. 


\section{References}

Al-Haj, M. (2012). Education, empowerment, and control: The case of the Arabs in Israel. Suny Press.

Al Hamishmar. (1968, Dec. 31). Residential quarter for American immigrants will be built in the French Hill. Al Hamishmar (Hebrew).

Arar, K., \& Haj-Yehia, K. (2016). Higher education and the Palestinian Arab minority in Israel. Springer.

Bauman, Z. (2013). Liquid fear. New-York: John Wiley and Sons.

Blatman-Thomas, N. (2017). Commuting for rights: Circular mobilities and regional identities of Palestinians in a Jewish-Israeli town. Geoforum, 78, 22-32.

Boano, C. (2016). Jerusalem as a paradigm: Agamben's 'whatever urbanism' to rescue urban exceptionalism. City, 20(3), 455-471.

Bollens, S. A. (2000). On narrow ground: Urban policy and ethnic conflict in Jerusalem and Belfast. SUNY Press.

Bollens, S. A. (2018). Trajectories of Conflict and Peace: Jerusalem and Belfast Since 1994. Routledge.

Braier, M., \& Yacobi, H. (2017). The planned, the unplanned and the hyper-planned: dwelling in contemporary Jerusalem. Planning Theory \& Practice, 18(1), 109-124.

Cahaner, L., \& Mansfeld, Y. (2012). A voyage from religiousness to secularity and back: a glimpse into 'Haredi' tourists. Journal of Heritage Tourism, 7(4), 301-321. 
Castells, M. (1978). City, class and power. London: Macmillan.

Castells, M. (1983). The City and the Grassroots: A Cross-Cultural Theory of Urban Social Movement. London: Arnold.

Charmat, K., and McMullen, L. M. (2011). Five ways of doing qualitative analysis: Phenomenological psychology, grounded theory, discourse analysis, narrative research, and intuitive inquiry. New-York: Guilford Press.

Chiodelli, F. (2016). Shaping Jerusalem: Spatial Planning, Politics and the Conflict. Taylor \& Francis.

Choshen, M., Assaf-Shapira, Korach, M., Shemer, D., Kupered, A., and Shachar, Y. (Eds.) (2015). Jerusalem statistical Yearbook 2015. Jerusalem: Jerusalem Institute for Policy Research.

Choshen, M., Assaf-Shapira, Y., Kupered, A., and Shemer, D. (Eds.) (2017). Jerusalem statistical Yearbook 2017. Jerusalem: Jerusalem Institute for Policy Research.

Crang, M., \& Graham, S. (2007). SENTIENT CITIES Ambient intelligence and the politics of urban space. Information, Communication \& Society, 10(6), 789-817.

Dumper, M. (2005). The politics of Jerusalem since 1967. Columbia University Press.

Dumper, M. (2014). Jerusalem unbound: Geography, history, and the future of the Holy City. New York: Columbia University Press. 
Efron, N. J. (2003). Real Jews: Secular versus ultra-orthodox and the struggle for Jewish identity in Israel. Basic Books.

Falah, G. (1996). Living together apart: Residential segregation in mixed Arab-Jewish cities in Israel. Urban Studies, 33(6), 823-857.

Fregonese S. (2012). Urban Geopolitics 8 Years on: Hybrid sovereignties, the everyday, and geographies of peace. Geography Compass, 6(5), 290-303.

French Hill Neighborhood Council (FHNC) (2013-2017). Protocols of the French Hill Neighborhood Council Board. Retrieved 20 Oct 2017, from http://www.eshkolbagiva.org.i1/community-center/Board (Hebrew).

Gaffikin, F., \& Morrissey, M. (2011). Planning in divided cities. John Wiley \& Sons.

Goldhaber, R. (2007). A spatio-perceptual segregation model: A case study of Jewish and Arab experiences in Jaffa, Israel. Urban Geography, 28(6), 578-603.

Gonen, A. (1994). Continuity and change in the geography of Jewish middle class in the Jerusalem metropolitan area. In O. Ahimeir (Ed.), Jerusalem: State of affairs (pp. 47-85). Jerusalem: Israeli Defense Ministry and the Jerusalem Institute for Israel Studies (Hebrew).

Graham, S. (Ed.). (2008). Cities, war, and terrorism: Towards an urban geopolitics. John Wiley \& Sons.

Hamdan, H. (2006). Upper Nazareth as a mixed city: Palestinian migration and issues of spatial and social behavior. In Fenster T. and Yacobi, H., Israeli city or a city in Israel, (pp. 110-135). Jerusalem: Van Leer Institute. 
Harvey, D. (2007). Neoliberalism as creative destruction. The Annals of the American Academy of Political and Social Science, 610(1):21-44.

Herzog, H. (2007). Mixed cities as a place of choice: The Palestinian women's perspective. In D. Monterescu, D. and D. Rabinowitz (Eds.), Mixed towns, trapped communities: Historical narratives, spatial dynamics, gender relations and cultural encounters in Palestinian-Israeli towns (pp. 243-257). London and New-York: Routledge.

Hasson, S. (2002). The struggle for hegemony in Jerusalem: Secular and UltraOrthodox urban politics. Jerusalem: Floersheimer Institute for Policy Studies.

ICBS. (2017). Jerusalem population by sub-quarter and religion, 2015. Israeli Central Bureau of Statistics. Unpublished data.

Issar, Y. (2016). The Arab neighborhoods in East Jerusalem - Infrastructure and assessment research: Issawiya. Jerusalem: Jerusalem Institute for Policy Research (Hebrew).

Jerusalem Municipality. (2008-2016). Children of the French Hill by educational systems. Unpublished data.

Johnson, R. B., Onwuegbuzie, A. J., \& Turner, L. A. (2007). Toward a definition of mixed methods research. Journal of mixed methods research, 1(2), 112-133.

Kimmerling, B. (2001). The invention and decline of Israeliness: State, society, and the military. University of California Press. 
Kinnvall, C. (2016). The Postcolonial has moved into Europe: Bordering, security and ethno- cultural belonging. JCMS: Journal of Common Market Studies, 54(1), 152-168.

Kuperman, A., and Landa, L. (2009, Nov 30). The French Hill becomes Haredi. Behadrei Haredim (Hebrew).

Leitner, H., Sheppard, E. S., Sziarto, K., \& Maringanti, A. (2007). Contesting urban futures: Decentering neoliberalism. In Leitner, H., Peck, J., and Sheppard, E. S., Contesting neoliberalism: Urban frontiers, (pp. 1-25). New-York and London: Guilford Press.

Luz, N., \& Stadler, N. (2017). 8 Urban planning, religious voices and ethnicity in the contested of Acre, in Rokem \& Boano (Eds.). Urban Geopolitics: Rethinking Planning in Contested Cities (pp. 138-150). Routledge.

Malcov, Z. (2010, Oct 10). The French Hill wants a fence with Issawiya. Mynet (Hebrew). Retrieved 20 September 2017, from http://mynetjerusalem.co.il/article/145415.

Malcov, Z. (2012, June 18). The French Hill: "We'll open Cafes in Shabbat". Mynet (Hebrew). Retrieved 20 September 2017, from http://mynetjerusalem.co.il/article/252355/26.

Masry-Herzalla, A., and Razin, E. (2014). Israeli-Palestinian migrants in Jerusalem: An emerging middleman minority. Journal of Ethnic and Migration Studies, 40(7), 1002-1022. 
Monterescu, D. (2016). Mixed towns, trapped communities: Historical narratives, spatial dynamics, gender relations and cultural encounters in Palestinian-Israeli towns. Routledge.

Morris, B. (1989). The birth of the Palestinian refugee problem, $1947-$ 1949. Cambridge: Cambridge University Press.

Newman, D. (2006). The lines that continue to separate us: Borders in our borderless world. Progress in Human Geography, 30(2), 143-161.

Nofet Tzofim. (2017). Nofet Tzofim community Facebook page (Hebrew). Retrieved 20 September, 2017, from https://www.facebook.com/\%D7\%A7\%D7\%94\%D7\%99\%D7\%9C\%D7\%AA$\% \mathrm{D} 7 \% \mathrm{~A} 0 \% \mathrm{D} 7 \% \mathrm{~A} 4 \% \mathrm{D} 7 \% \mathrm{AA}-$ \%D7\%A6\%D7\%95\%D7\%A4\%D7\%99\%D7\%9D-1774283809557440/

Nolte, A., and Yacobi, H. (2015). Politics, infrastructure and representation: The case of Jerusalem's light rail. Cities, 43, 28-36.

Savitch, H. V. (2005). An anatomy of urban terror: lessons from Jerusalem and elsewhere. Urban Studies, 42(3), 361-395.

Shafir, G. (2018). From overt to veiled segregation: Israel's Palestinian Arab citizens in the Galilee. International Journal of Middle East Studies, 50(1), 1-22.

Pullan, W. (2011). Frontier urbanism: The periphery at the centre of contested cities. The Journal of Architecture, 16(1), 15-35. 
Pullan, W., and Yacobi, H. (2017). Jerusalem's colonial space as paradox. In Allegra, M., Handel, A., and Maggor, E. (Eds.), Normalizing Occupation: The Politics of Everyday Life in the West Bank Settlements (pp. 193-210). Bloomington and Indianapolis: Indiana University Press.

Rebhun, U., \& Malach, G. (2012). Demography, social prosperity, and the future of sovereign Israel. Israel Affairs, 18(2), 177-200.

Robinson, J. (2013). Ordinary cities: between modernity and development. Routledge.

Rokem, J. (2017). Ordinary Urban Geopolitics: Contrasting Jerusalem and Stockholm. In Urban Geopolitics (pp. 50-67). Routledge.

Rokem, J., \& Boano, C. (Eds.). (2017). Urban Geopolitics: Rethinking Planning in Contested Cities. Routledge.

Rokem, J., and Vaughan, L. (2017). Segregation, mobility and encounters in Jerusalem: The role of public transport infrastructure in connecting the 'divided city’. Urban Studies, 0042098017691465. doi:10.1177/0042098017691465.

Rosen, G., \& Charney, I. (2016). Divided we rise: politics, architecture and vertical cityscapes at opposite ends of Jerusalem. Transactions of the Institute of British Geographers, 41(2), 163-174.

Rosen, G., and Shlay, A. B. (2014). Whose right to Jerusalem? International Journal of Urban and Regional Research, 38(3), 935-950.

Sandercock, L. (2000). When strangers become neighbors: Managing cities of difference. Planning Theory and Practice, 1(1), 13-30. 
Sieber, S. D. (1973). The integration of fieldwork and survey methods. American journal of sociology, 78(6), 1335-1359.

Shilhav, Y. (1984). Spatial strategies of the "Haredi" population in Jerusalem. SocioEconomic Planning Sciences, 18(6), 411-418.

Shilhav, Y. (1993). The emergence of Haredi neighborhoods in Israeli urban centers. In Ben-Zadok, E. (Ed.), Local Communities and the Israeli Polity (pp. 157-188). Albany: Sunny Press.

Shlomo, O. (2017). The governmentalities of infrastructure and services amid urban conflict: East Jerusalem in the post Oslo era. Political Geography, 61, 224-236.

Shteinmatz, M. (2016). Jerusalem of Bourgeoise, Haredi and Arabs: How the capital of Israel has changed its face. Walla (Hebrew). Retrieved on Nov 21, 2017, from: https://news.walla.co.il/item/2967380.

Shtern, M. (2016). Urban neoliberalism vs. ethno-national division: The case of West Jerusalem's shopping malls. Cities, 52, 132-139.

Sibley, D. (1995). Geographies of exclusion: Society and difference in the west. London and New-York: Routledge.

Tzfadia, E., and Yacobi, H. (2011). Rethinking Israeli space: Periphery and identity. New York: Routledge.

Wacquant, L. (2008). The militarization of urban marginality: Lessons from the Brazilian metropolis. International Political Sociology, 2(1), 56-74. 
Weingrod, A., and Manna, A. (1998). Living along the seam: Israeli Palestinians in Jerusalem. International Journal of Middle East Studies, 30(3), 369-386.

Yacobi, H. (2009). The Jewish-Arab city: Spatio-politics in a mixed community. London and New-York: Routledge.

Yacobi, H. (2015). Jerusalem: from a 'divided' to a 'contested' city—and next to a neo-apartheid city? City, 19:4,579-584

Yacobi, H., and Tzfadia, E. (2017). Neo-settler colonialism and the re-formation of territory: Privatization and nationalization in Israel. Mediterranean Politics, 1-19.

Yacobi, H., and Pullan, W. (2014). The geopolitics of neighborhood: Jerusalem's colonial space revisited. Geopolitics, 19(3), 514-539. doi:10.1080/14650045.2013.857657.

Yiftachel, O. (1994). The dark side of modernism: Planning as control of an ethnic minority. In S. Watson and K, Gibson (Eds.), Postmodern cities and spaces (pp. 216-239). Oxford: Blackwell.

Yiftachel, O., and Yacobi, H. (2002). Planning a bi-national capital: Should Jerusalem remain united? Geoforum, 33(1), 137-144.

Zicherman, H., and Cahaner, L. (2012). Modern Ultra-Orthodoxy: The evolution of the Ultra-Orthodox middle class in Israel. Jerusalem: The Israel Democracy Institute (Hebrew).

Zorea, A. (2017, March 13). The French Hill: Image installations of neighborhoods' women residents. Kol Hair (Hebrew). 
